\title{
Household demand and supply for clean groundwater in the Mekong Delta, Vietnam
}

\author{
Vo Thanh Danh ${ }^{*}$ and Huynh Viet Khai
}

\begin{abstract}
Background: Because of the important role of groundwater and limited studies related to groundwater, in order to prevent the possibility of deterioration of this valuable natural water resource in the Vietnamese Mekong Delta studies on the analysis of household behavior of private tube-well and groundwater supply unit (GSU) water users to identify the demand and supply situation of groundwater and the proper management of groundwater are very essential.

Methods: The study identified the options available to households in the Mekong Delta of Vietnam in dealing with the quality of their water sources and presented an analysis of their switching behavior across such sources by using various regression models (the multiple regression, the two-step switching regression, and the linear probability).

Results: This study found that the water consumption of GSU users was significantly lower compared with those using private tube-wells for their water needs. For non-GSU users, the probability of switching to GSU water was found to be 37 percent. Income played an important role in encouraging households to switch to using GSU water. In addition, the interaction effects between income and the education level of the head of the household and the length of the time the household had settled in the community increased the probability of switching to GSU water.

Conclusion: This result supports the conclusion that switching from private tube-wells to GSU water would encourage water saving, thus preventing ground water resources from being over-extracted.
\end{abstract}

\section{Background}

Vietnam's Mekong Delta (VMD) is home to 18 million people who account for $21 \%$ of the country's population. There is a huge demand for clean water by its residents. A fraction of this comes from groundwater. Currently, groundwater is extracted in the VMD by households from shallow tube-wells with a depth of 80 to $120 \mathrm{~m}$ and groundwater plants digging deep wells to a depth of 200 to $450 \mathrm{~ms}$. There are now more than 1 million shallow tube-wells. Forty percent of them are UNICEF-made types with an extraction volume of 430,000 $\mathrm{m}^{3} /$ day. The groundwater of the VMD has four layers; namely, Pleistoxen, Plioxen, Mioxen, and Holoxen. There are only three groundwater layers, however, that can be extracted for clean water use purposes. The one not included is the Holoxen layer due to bio-micro pollution. However, even for the Pleistoxen layer, the high level of nitrate pollution and high chlorine concentration cause many health hazards for the residents.

* Correspondence: vtdanh@ctu.edu.vn

Agricultural, Resource and Environmental Economics, School of Economics and Business Administration, Can Tho University, Can Tho, Vietnam
Besides the possibility of pollution created by agricultural practices that use chemical fertilizers and pesticides, pollution also happens due to worn-out tube-wells. Pollution from the surface seeps over time into groundwater layers and destroys the quality of the water. Overextraction, saltwater intrusion, and pollution are problems linked to the groundwater supply situation in the VMD. Unrestricted access increases the number of private tube-wells. As a result, over-extraction can be said to be happening in the whole delta. The phenomenon of groundwater table reduction in the dry season reduces the sustainability of groundwater supply and increases the cost of water pumping. Another impact of overextraction is saltwater intrusion. The quality of the groundwater aquifer gets degraded, and in some cases, the saltwater intrusion also destroys the water quality of the groundwater aquifer. Finally, the possibility of groundwater pollution from various sources will endanger the quality of the groundwater in the long run. If these adverse impacts are not prevented or eliminated, the availability of clean water supply will be severely compromised. 
In the rural area especially, although there is a network of rivers, the use of clean water is limited due to pollution from agricultural production activities, aquaculture, and salination in the dry season. A fraction of clean water comes from ground water. Currently, ground water is mostly extracted from shallow tube-wells at the household level and ground water plants that are installed by the government via a rural development program, namely the groundwater supply unit (GSU) project. The objective is to provide rural people with access to clean water for domestic use. The fact that the river water is highly polluted and of inferior quality in the dry season and rainwater is hard to collect and store makes ground water the best source of clean water. Clean water supply in the VMD is complex.

There have recently been some water-related studies in Vietnam. The paper written by Phuong and Gopalakrishnan (2003) estimated the loss of water resource values due to pesticide contamination in the Mekong Delta of Vietnam, while Nam and Son (2005) recognized household's WTP for improved water services in Ho Chi Minh city, Vietnam. The study by Danh (2008) analyzed the households' motivations and their willingness to pay for the program of groundwater protection in the Mekong Delta. The study performed that the residents in Mekong Delta were willing to pay approximately 141,730 VND (US $\$ 8.86$ ) per household a year. Groundwater could be an inferior good with the negative income effect found in the demand for clean groundwater. Khai (2014) estimated the Mekong Delta urban households' willingness to pay of 267,550 VND (US\$12.67) per household, nearly equal to $1.41 \%$ of the average annual income of households in the study area, for the surface water improvement project. Beside the results of previous studies, the analysis of household behavior of private tube-well and GSU water users to identify the demand and supply situation of groundwater and the proper management of groundwater is certainly necessary to prevent the possibility of deterioration of the valuable natural water resource. To partly answer these issues and contribute to the literatures of water-related studies in Vietnam, this paper aims to identify clean water use options, explore the advantages and disadvantages of each option, and analyze household switching behavior across water sources. A survey of non-GSU users (i.e., households that own private tube-wells) and GSU users (i. e., households that buy water from GSUs) was undertaken. An analysis of switching behavior from non-GSU use to GSU use was made. For current GSU users, factors that affected the choice of GSU water in terms of water quantity and quality were identified. Moreover, the reasons for the preferences in water sources were explored for both GSU and non-GSU users. Finally, the factors affecting the operation and management of GSU plants were also studied.

\section{Background and data collection}

A nationwide program of clean water supply for rural areas was launched in the region in 1986. As a result, rural clean Water and Environment Management Centers (WEMCs) were established in the VMD via the cooperation between the Vietnamese government and UNICEF. The main objectives of the WEMCs were to help the poor people in the rural areas to be able to access clean water through groundwater projects. Besides building private small-scale tube-wells, the project has launched an impressive plan of establishing a network of GSUs covering whole rural areas. This network has been established by WEMCs and operated by partners who are the landowners of the areas where GSU plants are located. Moreover, the GSU project is expected to solve the issue of depletion of groundwater overuse by households. That is, as the household uses priced groundwater, the quantity of water used will be affected by the price scheme and is expected to adjust itself to an efficient level. It differs from the case of private tubewells where the quantity of groundwater used depends just on the needs of the household.

This study was conducted in Can Tho city, one of GSU project implemented areas in the VMD. Can Tho city has abundant surface water and groundwater reserves. A network of rivers and canals is interlaced with a total length of $4,300 \mathrm{~km}$ and a density of $1.8 \mathrm{~km} / \mathrm{km}^{2}$. The rivers are a rich source of water in the rainy season. However, in the dry season, most rivers and canals are salinized and polluted by agro-chemicals. Consequently, surface water cannot be used for domestic purposes in the remote areas. Can Tho's total groundwater reserve is about 5.5 million $\mathrm{m}^{3}$ with a potential extractable quantity of $763,531 \mathrm{~m}^{3} /$ day, $384,562 \mathrm{~m}^{3} /$ day, and $1,450,407 \mathrm{~m}^{3} /$ day for the Pleistoxen, Plioxen, and Mioxen layers, respectively. So far, the groundwater is extracted mostly from the Pleistoxen layer. In the year 2000, the total extracted amount of groundwater for domestic use was about $57,000 \mathrm{~m}^{3} /$ day (Can Tho DARD 2002).

There were three different questionnaires for three types of respondents in the survey; namely, the GSU managers, the GSU users, and the non-GSU users. For all three types of questionnaire, there were two common sections: information about the characteristics of the respondents and information on the supply of and demand for water. Questions about the pollution of groundwater resources were asked to evaluate the effects of knowledge on pollution in selecting water sources to use. The focus group discussion method was used to design the questionnaire. Then, pre-test surveys were done to ascertain the appropriateness and level of difficulty of the questions. Based on the results of the pre-test surveys, the questionnaires were redesigned. Finally, before doing the field surveys, pilot surveys were conducted. 
A sample of $81 \mathrm{GSU}$ plant managers was interviewed on the status of groundwater supply. The number of GSU plants as per the list from WEMC was 394 at the time of the study. A fifth of this was randomly selected. On the demand side, a sample of 127 GSU users and 233 nonGSU users were interviewed. Four out of twelve districts except two urban districts were selected randomly to conduct the surveys. These were Cai Rang, Long My, Phong Dien, and O Mon. As a first step, a GSU plant was randomly positioned in each district. Based on the number of clients that the GSU manager of the designated plant accounted for, interval sample groups with a minimum of 30 GSU-users and 60 (double the number) non-GSU users was selected in each district. To find out how many households there were in the area where GSU plants were located, the local authority was contacted prior to the interviews. The surveys for all three questionnaires were implemented by face-to-face interviews, each taking about 40 to 50 minutes. To be sure that the sampling procedure was properly followed by the numerators, a team of two experienced field persons supervised the surveys. A quality check resulted in the dropping of seven from 367 questionnaires.

Generally, the demographic characteristics of water users sampled were similar in age, education status, years of residence in the study site, and household size. However, there was a difference in the mean household incomes of GSU users and non-GSU users. The nonGSU users' average household income was significantly higher than the GSU users' average household income. For the water supply side, the mean education level of the GSU managers was secondary school level and the designed capacity (number of households) of the GSUs ranged from 45 to 90 (See Table 1 showing the descriptive statistics of water actors in the survey).

Some of the socio-economic variables were used to analyze the water supply situation of GSU plants and water demand situation of both the current GSU users and the non-GSU users (potential GSU users). These economic variables with their definitions are presented in Table 2.

\section{Methods}

There are many ways to analyze the demand of household water use depending on different purposes. Ahmad et al. (2005) applied a multinomial logit model to estimate the value of arsenic-free drinking water in Bangladesh, while Kremer et al.(2008) applied the two-step regression with two treatments to understand household behavior of WaterGuard use for treatment of drinking water in homes in Kenya, and Hamoudi et al. (2012) used the approach of difference in differences (DiD) estimator to recognize the relationship between the information about contamination in household's drinking water and water handling behavior. In this study, various regression
Table 1 Descriptive statistics of water actors

\begin{tabular}{|c|c|c|c|c|}
\hline Characteristic & Mean & Min. & Max. & S.D. \\
\hline \multicolumn{5}{|l|}{ Non-GSU users } \\
\hline Age (in years) & 48 & 17 & 82 & 13.5 \\
\hline Education level $^{a}$ & 3 & 1 & 5 & 0.86 \\
\hline Number of years of residence & 32 & 1 & 79 & 16.65 \\
\hline Number of family members & 5 & 1 & 12 & 1.87 \\
\hline Income per month (million VND) & 3.27 & 0.25 & 25.0 & 3.72 \\
\hline \multicolumn{5}{|l|}{ GSU users } \\
\hline Age (in years) & 45 & 17 & 86 & 14.8 \\
\hline Education level $^{a}$ & 3 & 1 & 5 & 0.81 \\
\hline Number of years of residence & 31 & 1 & 85 & 17.14 \\
\hline Number of family members & 5 & 1 & 12 & 1.62 \\
\hline Income per month (million VND) & 2.28 & 0.25 & 14.0 & 1.75 \\
\hline \multicolumn{5}{|l|}{ GSU managers } \\
\hline Age (in years) & 43 & 19 & 69 & 12.55 \\
\hline Education level $^{a}$ & 3 & 2 & 5 & 0.77 \\
\hline $\begin{array}{l}\text { Designed capacity (number } \\
\text { of households) }\end{array}$ & 157 & 90 & 450 & 65.67 \\
\hline $\begin{array}{l}\text { Number of years GSU established } \\
\text { (up to 2006) }\end{array}$ & 3 & 1 & 7 & 1.71 \\
\hline
\end{tabular}

Note: ${ }^{\mathrm{a}} 1,2,3,4$, and 5 stand for illiterate, primary level (1 to 5 years), secondary level (6 to 9 years), high school (10 to 12 years), and tertiary level $(>12$ years), respectively.

models (the multiple regression, the two-step switching regression, and the linear probability) were used to analyze the current supply and demand situation for clean groundwater. For example, forecasting of demand and supply patterns was performed using the two-step switching regression and linear probability models (LPM). To evaluate the effects of socio-economic factors on changing supply and demand patterns, the discriminant analysis (DA) method was applied.

\section{Multiple regression model}

This was used to explain the correlations between the socio-economic characteristics of GSU households and GSU managers, and GSU water expenditure and the amount of water sold, respectively. The multiple regression model is presented as follows:

$$
Y_{i}=a_{0}+a_{1} X_{1 i}+a_{2} X_{2 i}+\ldots .+a_{k} X_{k i}+\ldots+a_{n} X_{n i}+\varepsilon_{i}
$$

where $Y_{i}$ is a vector of the dependent variable representing either GSU water expenditure of a GSU household or the amount of water sold by a GSU plant; $X_{k i}$ is the vector of explanatory variables representing the socio-economic characteristics of the kth GSU household or GSU manager, and the $i$ th household or GSU manager selected in the sample. 
Table 2 Definitions of variables used in the study

\begin{tabular}{|c|c|}
\hline Variable & Definition \\
\hline \multicolumn{2}{|c|}{ General sample and non-GSU user sample } \\
\hline Sex & Sex (1 for male; otherwise 0 ) \\
\hline Age & Age in years \\
\hline Education & $\begin{array}{l}\text { Educational level (1, 2, 3, 4, and } 5 \text { for illiterate, primary, secondary, high school, } \\
\text { and tertiary level, respectively) }\end{array}$ \\
\hline Occupation & Dummy variable of occupation ( 1 for farmer; otherwise 0 ) \\
\hline Ethnic & Ethnic (1 for Kinh; otherwise 0) \\
\hline Residence & Years of residence in the study site \\
\hline Family number & Number of family members \\
\hline Income & Monthly household income (million VND) \\
\hline Distance & Distance from household to nearest GSU (km) \\
\hline \multicolumn{2}{|l|}{ GSU user sample } \\
\hline District-D1 & District (1 for Phong Dien District; otherwise 0) \\
\hline District-D2 & District (1 for Cai Rang District; otherwise 0) \\
\hline District-D3 & District (1 for O Mon District; otherwise 0) \\
\hline Education-D1 & Educational level ( 1 for illiteracy or primary school; otherwise 0 ) \\
\hline Education-D2 & Educational level ( 1 for secondary school; otherwise 0) \\
\hline Residence-D1 & Years of residence ( 1 for prior to 1975; otherwise 0) \\
\hline Residence-D2 & Years of residence ( 1 for 1976 to 1985; otherwise 0) \\
\hline Residence-D3 & Years of residence ( 1 for 1986 to 1995; otherwise 0) \\
\hline Amount 1 & GSU water amount bought monthly \\
\hline \multicolumn{2}{|l|}{ GSU manager sample } \\
\hline Depth & Depth of GSU well (m) \\
\hline Manager education & Dummy variable of educational level ( 1 for high school or tertiary; otherwise 0 ) \\
\hline Years GSU established & Number of years the GSU plant has been established (up to 2006) \\
\hline Amount 2 & GSU water quantity sold monthly $\left(\mathrm{m}^{3}\right)$ \\
\hline Capacity & Designed capacity (number of households) \\
\hline
\end{tabular}

\section{Two-step Heckman switching regression model}

This was used to model the decision-making behavior of households. A non-GSU household has to decide, first, whether or not to buy GSU water, and second, how much to buy. Following Maddala (1983), a statistical model was formulated as follows:

$$
Y_{i}=a_{0}+a_{1} X_{1 i}+a_{2} X_{2 i}+\ldots .+a_{k} X_{k i}+\ldots .+a_{n} X_{n i}+\varepsilon_{i}
$$

$Y_{i}$ is observed if and only if $b_{0}+b_{1} X_{1 i}+b_{2} X_{2 i}+\ldots .+$ $b_{k} X_{k i}+\ldots .+b_{n} X_{n i}+\gamma_{i}>0$,

Covariance $\left(\varepsilon_{\dot{v}} \gamma_{i}\right) \neq 0$,

where $Y_{i}$ is the vector of dependent variable representing the demands of non-GSU household $i$ th; $X_{k i}$ is the vector of explanatory variables presenting socio-economic characteristics of the $k$ th non-GSU household, and the $i$ th non-GSU household selected in the sample; $a_{n}$ and $b_{k}$ are estimated coefficients; $\varepsilon_{i}$ and $\gamma_{i}$ are the error terms.
The difference between Equations 1 and 2 is that $Y_{i}$ in Equation 1 is an observable variable (or actual variable) while $Y_{i}$ in Equation 2 is an unobservable variable (or latent variable).

\section{Linear probability model}

This was used to forecast the demand or supply in the groundwater market. The results of the model allow one to make a prediction about the probability of a non-GSU household switching to GSU water and the probability of a higher amount of GSU water being sold during the dry season compared with the volume sold during the rainy season as determined by characteristics of nonGSU households and GSU managers, respectively. The model is stated as follows:

$$
Y_{i}=a_{0}+a_{1} X_{1 i}+a_{2} X_{2 i}+\ldots+a_{k} X_{k i}+\ldots .+a_{n} X_{n i}+u_{i}
$$


where $Y_{i}$ is the vector of dependent variable (dichotomous variable: 1 for willingness to switch to GSU water; 0 for otherwise); $X_{k i}$ is the vector of explanatory variables representing the socio-economic characteristics of the $k$ th non-GSU household or GSU manager and the technical nature of the $i$ th GSU plant.

\section{Discriminant analysis model}

To identify factors distinguishing the difference in water demand by GSU households and the difference between the GSU water quantities sold in the dry season and the rainy season, the DA model was used. It is presented below.

$$
D=\alpha+\beta_{1} X_{1}+\beta_{2} X_{2}+\ldots . .+\beta_{n} X_{n}
$$

where $D$ is a discriminant or dependent variable representing either the water demand of a GSU household or water sold by a GSU plant; $X_{n}$ are predictors or independent variables; $\alpha$ and $\beta_{n}$ are standardized canonical discriminant coefficients ${ }^{\mathrm{a}}$.

The reason for using a DA function instead of a regression model to distinguish the difference in water demand by GSU households and the difference in GSU water quantities sold in the dry season and the rainy season is that the information on the quantity of water used by the consumer or sold by the supplier in the different seasons could not be collected at the time of the survey.

\section{Results and discussion}

\section{Groundwater demand analysis}

Three main sources of water could be found in the study area. Generally, the preference of the households for the different water sources was ranked as follows: $52.4 \%$, $24.5 \%, 21 \%$, and $2.1 \%$ for tube-wells, rain water, GSU water, and river water, respectively. The results showed that groundwater was the most preferred water source. Rain water ranked second while river water was not preferred at all. The serious pollution of the rivers in recent years has discouraged people from using river
Table 3 Reasons for choice of water sources for domestic use of the average household

\begin{tabular}{lccc}
\hline Reasons for choice & \multicolumn{3}{c}{ Sources of water (\%) } \\
\cline { 2 - 4 } & Groundwater & Rain water & River water \\
\hline Reliability & 67.4 & 16.9 & 41.2 \\
Availability & 27.9 & 62.8 & 71.9 \\
Convenience & 15.9 & 25.0 & - \\
Health concerns & 63.9 & 35.8 & 1.8 \\
Other water source polluted & 78.1 & 20.3 & - \\
Low cost & 36.9 & 25.0 & 36.8 \\
\hline
\end{tabular}

water. Meanwhile, rain water presented problems of air pollution, reliability, and storage. It can be stated that for domestic purposes, people in the VMD prefer to use groundwater over other water sources. However, they still use other water sources like rain water and river water for their daily activities. Nearly two-thirds of the households believed that using groundwater would allow them to avoid health hazards. The reliability of groundwater sources was also appreciated by the households. For the rain water and river water sources, availability and reliability were cited as the most important reasons for continued domestic use (See Table 3 presenting the main reasons for the households' choice of water sources for domestic use).

Table 4 shows the ranking of water sources used for different kinds of activities. There was a marked difference in the behavior of the two water user groups in terms of the purposes of water use. Non-GSU households used groundwater, rain water, and river water mainly for drinking, cooking, bathing, and washing while GSU households did not use river water for drinking and cooking. This was the biggest difference in the pattern of water use of the two water user groups in the study. The GSU households used groundwater for cooking and drinking, the most important reasons for getting clean and sanitary water supply. Nearly three-fourths and two-fifths of GSU households used groundwater and rain water, respectively, for

Table 4 Ranking of water source by purpose of use

\begin{tabular}{|c|c|c|c|c|c|c|}
\hline \multirow[t]{2}{*}{ Water sources } & \multicolumn{6}{|c|}{ Purpose of use (\%) } \\
\hline & Drinking & Cooking & Bathing & Washing & Gardening & Other \\
\hline \multicolumn{7}{|l|}{ Non-GSU users } \\
\hline Groundwater & 61.8 & 90.4 & 97.9 & 93.6 & 39.3 & 24.5 \\
\hline Rain water & 57.7 & 24.4 & 3.4 & 3.0 & - & - \\
\hline River water & 6.7 & 9.8 & 8.5 & 25.2 & - & 6.4 \\
\hline \multicolumn{7}{|l|}{ GSU users } \\
\hline Groundwater & 74.8 & 100.0 & 100.0 & 77.2 & 3.1 & 4.7 \\
\hline Rain water & 41.7 & 18.9 & - & - & - & - \\
\hline River water & - & - & 11.0 & 37.8 & 34.6 & 7.9 \\
\hline
\end{tabular}


drinking; and $100 \%$ and one-fifth of them used groundwater and rain water, respectively, for cooking. Meanwhile, nearly $62 \%$ and $58 \%$ of the non-GSU households used groundwater and rain water, respectively, for drinking; and more than $90 \%$ and $24 \%$ of them used groundwater and rain water, respectively, for cooking. Groundwater was also the most important source used by GSU users and non-GSU users for other activities such as bathing, washing, gardening, and so on.

\section{Demand of non-GSU users}

To forecast the probability that a non-GSU household will switch to using GSU water, a LPM was used in the study. The coefficients estimated for economic variables in the model are explained as the probability of switching to GSU water use. As a limitation of the LPM model, the change in the probability of the switching decision is assumed to be linear. By summing the probabilities of changing with respect to economic variables, the probability of the willingness-to-switch to GSU water by a representative household can be predicted.

Table 5 and Table 6 show the estimation and sensitivity analysis of factors affecting the change in probability of switching. It is seen that important household decisions are usually made by the household head. In the study, demographic characteristics of the head that were taken into account were gender, age, education status, and occupation. Firstly, at the significance level of $10 \%$, if the head of the household was male, the probability of switching was $53 \%$ higher than if the head was female. Male-headed households made up $48.5 \%$ of the total. This means that the probability of switching was $41.7 \%$ for $48.5 \%$ of household population. The head's age was also an important factor affecting the choice. The probability of switching by younger people was significantly higher than for older people. It showed that if the head of the household was less than 40 years old, the probability of switching was higher by $12 \%$ than if head of household was over 60 years of age. Education status had a positive relationship to willingness-to-switch. A head with a high school education had a higher probability of $9.8 \%$ and $5.7 \%$ of switching than one who finished only primary school and secondary school, respectively. However, the result for the latter was not statistically significant. The occupation of the household head did not significantly affect the probability of switching to GSU water.

Other household characteristics that were taken into account in the decision to switch to GSU water included: the time/year of settlement (to indicate the years of residence in the area), the size of the household, and the household income. Firstly, a household which had settled prior to 1985 had a lower probability of switching than a household which had settled between 1986 and 2005. For example, the probability of switching of a household which had settled prior to year 1975 was 18\% lower than that of a household which had settled from 1996 to 2005. It is probable that the quality of groundwater from the private tube-wells that were built prior to 1975 was better so much so that the households preferred tube-well water than GSU water. The longer the household had settled in the area, the lower the probability of switching was. Secondly, the size of the household had a positive relationship with the probability of switching to GSU water. As the size of the household increased, the probability of switching increased. A household that had more than six people had a higher probability of switching than a household with fewer than four people. Lastly, households with lower incomes were more likely to switch. At the 5\% significance level, households with a mean income of 2 to 5 million VND and higher than 5 million VND had a lower probability of switching at $6.2 \%$ and $19.5 \%$, respectively, compared with those with mean monthly incomes of less than 2 million VND. This result is consistent with the fact that income is an important determinant of the demand function.

For the interaction effect between household income and the time of settlement, the results in Table 6 showed that households with incomes from 2 to 5 million VND which had settled from 1986 to 1995 had a lower probability of switching by $32.6 \%$ compared with the households which had settled at the same time, but which had lower incomes (less than 2 million VND). In the same way, the households earning more than 5 million VND which had settled from 1986 to 1995 had a lower probability of switching by $40.8 \%$ compared with those which had settled in the same period, but with income levels of less than 2 million VND. This result proved that household income and time of settlement/years of residence were very important factors affecting the demand for GSU water by non-GSU households. If both of them were simultaneously taken into account, income showed a greater effect.

To predict the demand for GSU water by non-GSU households, the two-step Heckman switching regression decision model was used. According to the model, the decision to switch to GSU water by a non-GSU household is logically a two-step process. Firstly, if a non-GSU household decides to connect to a GSU, who will then have to decide how much GSU water to buy. The first step in switching was analyzed above in terms of probability. The second step of forecasting the quantity of water demanded was described in Equation 2. The results of estimating the model are presented in Table 7.

All variables used in the LPM model were repeated in the HSR model. In addition, a distance variable from the house to the nearest GSU plant was incorporated in the model (see Table 7). The estimated coefficient, however, was not statistically significant although the sign of the 
Table 5 Results of LPM estimation on switching to GSU water use

\begin{tabular}{|c|c|c|c|c|c|}
\hline Explanatory variable & & Coefficient & $t$-value & $R^{2}$ & Number of observations \\
\hline \multicolumn{6}{|l|}{ No interaction effect } \\
\hline Constant & & 0.853 & $5.028^{* * *}$ & & \\
\hline \multicolumn{6}{|l|}{ Sex } \\
\hline Female & & - & - & & \\
\hline Male & & 0.053 & $1.746^{*}$ & & \\
\hline \multicolumn{6}{|l|}{ Age } \\
\hline$\leq 40$ years & & - & - & & \\
\hline 41 to 60 years & & -0.118 & $-1.622^{\mathrm{ns}}$ & & \\
\hline$\geq 61$ years & & -0.17 & $-1.869^{*}$ & & \\
\hline \multicolumn{6}{|l|}{ Education } \\
\hline High school and above & & - & - & & \\
\hline Primary school & & -0.098 & $-1.741^{*}$ & & \\
\hline Secondary school & & -0.057 & $-1.423^{\mathrm{ns}}$ & & \\
\hline \multicolumn{6}{|l|}{ Occupation } \\
\hline Other careers & & - & - & & \\
\hline Farmers & & 0.019 & $1.156^{\mathrm{ns}}$ & & \\
\hline \multicolumn{6}{|l|}{ Residence } \\
\hline 1996 to 2005 & & - & - & & \\
\hline$\leq 1975$ & & -0.181 & $-1.86^{*}$ & & \\
\hline 1976 to 1985 & & -0.1 & $-1.571^{\mathrm{ns}}$ & & \\
\hline 1986 to 1995 & & 0.025 & $1.743^{*}$ & & \\
\hline \multicolumn{6}{|l|}{ Family number } \\
\hline$\leq 3$ persons & & - & - & & \\
\hline 4 to 5 persons & & 0.041 & $1.591^{\mathrm{ns}}$ & & \\
\hline 6 to 7 persons & & 0.039 & $1.906^{*}$ & & \\
\hline$\geq 8$ persons & & 0.058 & $1.719^{*}$ & & \\
\hline \multicolumn{6}{|l|}{ Income } \\
\hline$\leq 2$ million VND & & - & - & & \\
\hline 2 to 5 million VND & & -0.062 & $-2.256^{* *}$ & & \\
\hline$>5$ million VND & & -0.195 & $-2.561^{* *}$ & & \\
\hline \multicolumn{6}{|l|}{ Interaction effect } \\
\hline Income & Year of taking up residence & & & & \\
\hline 2 to 5 million VND & $\leq 1975$ & 0.107 & $1.591^{\mathrm{ns}}$ & & \\
\hline 2 to 5 million VND & 1976 to 1985 & -0.163 & $-1.649^{*}$ & & \\
\hline 2 to 5 million VND & 1986 to 1995 & -0.326 & $-2.151^{* *}$ & & \\
\hline$>5$ million VND & $\leq 1975$ & 0.106 & $1.344^{\mathrm{ns}}$ & & \\
\hline$>5$ million VND & 1976 to 1985 & 0.092 & $1.356^{\mathrm{ns}}$ & & \\
\hline \multirow[t]{3}{*}{$>5$ million VND } & 1986 to 1995 & -0.408 & $-2.986^{* * *}$ & & \\
\hline & & & & 0.210 & \\
\hline & & & & & 233 \\
\hline
\end{tabular}

Notes: $* * *{ }^{* *},{ }^{*}$ indicate significance at $1 \%, 5 \%$, and $10 \%$ levels, respectively; ns, not significant.

coefficient was consistent with the hypothesis that the farther the household was from the GSU plant, the less amount of water was demanded. In the model, there were only two variables - education status and occupation - that turned out to be statistically significant. Therefore, they can be used to forecast the demand for GSU water by a 
Table 6 Sensitivity analysis of predicted probability of switching to GSU water use

\begin{tabular}{|c|c|c|c|c|c|c|c|c|c|}
\hline \multirow{3}{*}{ Interaction form } & \multirow{3}{*}{ Baseline $^{a}$} & \multicolumn{8}{|c|}{ Scenario } \\
\hline & & \multirow[t]{2}{*}{$\begin{array}{l}\text { Young people } \\
\text { (age } \leq 40)\end{array}$} & \multirow[t]{2}{*}{$\begin{array}{l}\text { Secondary } \\
\text { education }\end{array}$} & \multicolumn{2}{|c|}{ Year of taking residence } & \multicolumn{2}{|c|}{$\begin{array}{l}\text { Number of persons } \\
\text { in household }\end{array}$} & \multicolumn{2}{|c|}{ Income } \\
\hline & & & & $\begin{array}{l}1976 \text { to } \\
1985\end{array}$ & $\begin{array}{l}1996 \text { to } \\
2005\end{array}$ & $\leq 3$ & 6 to 7 & $\leq 2$ million & $>5$ million \\
\hline No interaction effect & 0.374 & 0.492 & 0.415 & 0.455 & 0.555 & 0.333 & 0.333 & 0.569 & 0.507 \\
\hline \multicolumn{2}{|l|}{ Interaction effect } & \multicolumn{3}{|c|}{ Education } & \multicolumn{5}{|c|}{ Year of taking up residence } \\
\hline $\begin{array}{l}\text { Income at } 2 \text { to } 5 \text { million } \\
\text { VND and secondary } \\
\text { education }\end{array}$ & 0.54 & $\begin{array}{l}\text { Primary } \\
\text { School }\end{array}$ & $\begin{array}{l}\text { Secondary } \\
\text { school }\end{array}$ & $\begin{array}{l}\text { High school } \\
\text { and Tertiary }\end{array}$ & Prior to 1975 & 1976 & 1985 & $\begin{array}{l}1986 \text { to } \\
1995\end{array}$ & $\begin{array}{l}1996 \text { to } \\
2005\end{array}$ \\
\hline $\begin{array}{l}\text { Income at } 2 \text { to } 5 \text { million } \\
\text { and year of taking } \\
\text { residence is prior to } 1975\end{array}$ & 0.481 & & & & & & & & \\
\hline \multicolumn{10}{|l|}{ Income } \\
\hline 2 to 5 million VND & - & 0.504 & 0.54 & 0.638 & 0.481 & & & 0.387 & 0.713 \\
\hline Higher than 5 million ND & - & 0.317 & 0.29 & 0.374 & 0.613 & & & 0.099 & 0.507 \\
\hline
\end{tabular}

non-GSU household. The marginal contribution of the number of years of going to school was 5,546 VND (or $\left.2.22 \mathrm{~m}^{3}\right)$. Meanwhile, it was found that farmers demanded more GSU water $\left(6,833\right.$ VND or $2.73 \mathrm{~m}^{3}$ more) than nonfarmers. This forecasting allows the GSU manager to make optimistic forecasts on the current mean monthly amount of GSU water sold (about $4.3 \mathrm{~m}^{3}$ ) (WEMC 2005) for higher educated users and farmers.

\section{Demand for GSU water}

Before switching to using GSU water, GSU households had used water from different sources such as rivers, tube-wells, and rain. There were $82 \%$ of them using river water; $74.8 \%$ using rain water; and $32.3 \%$ of them using tube-wells. After switching to GSU water, there was a change in the water use pattern of the households. More than one-third of the households who previously used water from the river stopped doing so while more than $41.2 \%$ of households who had previously used water from private tube-wells abandoned this water source. Moreover, the number of households using rain water decreased by about $40 \%$. Preferred water sources were GSUs, rain water, and tube-wells at the levels of $81.7 \%, 14.3 \%$, and $1.6 \%$, respectively. In addition, other water sources such as bottled water and vendor water were preferred only at the $2.4 \%$ level. Thus, groundwater was found to be the most preferred choice of GSU households.

On average, GSU households consumed $5.88 \mathrm{~m}^{3}$ of GSU water per month or nearly 431 /person/day. This consumption level was still very low in comparison with the WHO standard on clean water consumption, which was $120 \mathrm{l} /$ person/day, in rural areas. This shows that once domestic water was charged, the amount of clean water dropped to a lower level compared with the consumption levels of those using private tube-wells. For the rural sector, it could be that the income and price effects were important factors in determining how much water was bought. In addition, there was a difference in consumption levels in the rainy season and the dry season. Nearly two-thirds of the households used much more GSU water in the dry season than during the rainy season. The factors affecting the difference in the use of water is presented in Table 8 , and they were analyzed using the DA model. The DA function, i.e., Equation 4, identifies the factors that affect seasonal use of water.

Table 8 shows that the household income and time of settlement were the most important factors contributing to the difference in water consumption between the two seasons. The results did not, however, show a strong correlation between seasonal water consumption and

Table 7 Results of two-step Heckman switching regression estimation on GSU water demand

\begin{tabular}{|c|c|c|c|c|c|}
\hline $\begin{array}{l}\text { Explanatory } \\
\text { variable }\end{array}$ & Coefficient & $z$ & $P>z_{a b}$ & $\begin{array}{l}\text { Wald chi- } \\
\text { square (8) }\end{array}$ & $\begin{array}{c}\text { Number of } \\
\text { observations }\end{array}$ \\
\hline Constant & 4.95 & 0.31 & 0.756 & & \\
\hline Distance & -.008 & -0.48 & 0.623 & & \\
\hline Sex & 5.14 & 1.05 & 0.295 & & \\
\hline Age & -5.86 & -0.02 & 0.981 & & \\
\hline Education $^{a}$ & 5.55 & 1.71 & 0.087 & & \\
\hline Occupation & 6.83 & 1.73 & 0.083 & & \\
\hline Residence & -.002 & -1.31 & 0.192 & & \\
\hline $\begin{array}{l}\text { Family } \\
\text { number }\end{array}$ & .002 & 0.19 & 0.849 & & \\
\hline Income & .009 & 1.28 & 0.202 & & \\
\hline
\end{tabular}

18.76

195

Note: ${ }^{a}$ Number of school-going years.

Unit: thousand VND. 
Table 8 Results of discriminant analysis of the difference in GSU water use in the dry and rainy seasons

\begin{tabular}{lcccc}
\hline Variable & Standardized canonical discriminant coefficient & Structure matrix coefficient & $\boldsymbol{R}_{\mathbf{c}}$ & Wilks' lambda \\
\hline Income & 0.754 & 0.281 & \\
Family number & -0.543 & -0.114 & \\
Residence & 0.516 & 0.412 &
\end{tabular}

the size of the household although the partial contribution of the latter was large enough to explain the difference in water consumption between the two seasons.

To evaluate the marginal contribution of variables (representing the characteristics of the GSU household) to the cost for water consumption, a regression function was used in the study presented in Table 9. The estimation showed that all the variables were not statistically significant so they could not be used to explain the change in the cost of water consumption. However, dummy variables indicated that there was a very big difference in the cost allocation for water consumption depending on the location and the time of settlement of the household. In the areas where rivers are seriously salinized during the dry season like Long My District of Hau Giang Province, people are heavily dependent on groundwater. This could be the reason why the households located in Long My spent more money on GSU water consumption than those located in the districts of O Mon, Phong Dien, and Cai Rang of Can Tho city. The households living in Hau Giang Province paid an additional 13,700 to 15,000 VND per month for GSU water consumption compared with the households living in Can Tho city. The situation of water resources is different from place to place in the VMD so we can expect that groundwater consumption will also be different from area to area. The results in Table 9 also show that the cost of water consumption is not the same if the time of settlement is different. People who had settled in the area during the period 1996 to 2005 spent less money on GSU water consumption than those who had settled earlier.

\section{Groundwater supply analysis}

To measure the impact of factors affecting the quantity of water sold by GSU plants, a regression function was used. The three variables shown in Table 10 are the distance from the GSU plant to the center of the village or commune; the education level of the GSU manager; and the number of years the GSU plant had been established. All coefficient signs estimated were consistent with the hypotheses. Distance did not have a large effect on the amount of water sold although the estimation showed that the further the GSU plant was from the center of the village, the less water quantity was sold. It can thus be said that distance was not an important factor affecting the quantity of water sold. It is reasoned that the education level of the GSU manager played an important role in the success of the GSU. Managers who had tertiary education sold much more water than those with less education. Specifically, the mean amount of water sold by the former was higher by $150 \mathrm{~m}^{3} /$ month than that sold by the latter. Finally, the number of years of establishment of the GSU had a positive impact on the water quantity sold with a partial contribution of $61.5 \mathrm{~m}^{3}$.

To identify the factors affecting the difference in water quantity sold in the dry and rainy seasons, a DA function with four predictor variables was used in the study. The reason for using the DA approach instead of a regression analysis was because the quantitative data on water sold in the dry season and the rainy season was not collected in the survey. The results in Table 11 show that three variables namely, distance from the GSU plant to the center of the village or commune, the depth of the GSU well, and the designed capacity in terms of the

Table 9 Results of the regression analysis of monthly water cost paid by GSU users

\begin{tabular}{lcccc}
\hline Explanatory variable & Coefficient & $\boldsymbol{t}$-value & $\boldsymbol{R}^{\mathbf{2}}$ & $\boldsymbol{F}$-test \\
\hline Constant & -32.40 & -.985 & & \\
District-D1 & -14.97 & $-3.957^{* * *}$ & & \\
District-D2 & -13.72 & $-3.329^{* * *}$ & & \\
District-D3 & -15.16 & $-3.749^{* * *}$ & & \\
Ln (family number) & 5.77 & .631 & & \\
Ln (income) & 2.93 & .656 & & \\
Occupation & 0.25 & .082 & \\
Sex & -0.36 & -.120 & \\
Ln (age) & 18.62 & 1.583 & & \\
Education-D1 & -1.03 & -.241 & & \\
Education-D2 & 0.10 & .030 & & \\
Residence-D1 & 4.49 & $1.999^{* *}$ & & $($ sig = 0000$)$ \\
Residence-D2 & 10.19 & $2.194^{* *}$ & & \\
Residence-D3 & 3.91 & .823 & & \\
& & & & \\
& & & & \\
& & & & \\
\hline
\end{tabular}

Note: ${ }^{* * *},{ }^{* *}$ indicate significance at $1 \%$ and $5 \%$ levels, respectively. Unit: thousand VND. 
Table 10 Results of the regression analysis of the amount of water sold monthly by GSU plants

\begin{tabular}{lcccc}
\hline Explanatory variable & Coefficient & $\boldsymbol{t}$-value & $\boldsymbol{R}^{\mathbf{2}}$ & $\boldsymbol{F}$-test \\
\hline Constant & 234.9 & $3.191^{* * *}$ & & \\
Distance & -26.0 & $-2.202^{* * *}$ & & \\
Manager education & 150.2 & $2.400^{* *}$ & & \\
Years GSU established & 61.5 & $4.050^{* * *}$ & & \\
& & & 0.296
\end{tabular}

10.391

$(\operatorname{sig}=.0000)$

Note: ${ }^{* * *, * *}$ indicate significance at $1 \%$ and $5 \%$ levels, respectively.

number of households that the GSU could serve, were important factors in explaining the difference of water quantity sold in the two seasons. Meanwhile, there was no strong support found for the existence of a relationship between the education level and the performance of the GSU in terms of the amount of water sold in the dry and rainy seasons.

In order to forecast the probability of higher performance of GSUs in the dry season, a LPM analysis was used in the study. The model used four predictors: the education status of the GSU manager, the years of establishment of the GSU (based on the time the GSU was built), the designed capacity, and the distance from the GSU to the center of the village or commune.

The LPM forecasts are given in Table 12. The results showed that for the representative $\mathrm{GSU}^{\mathrm{b}}$, the probability of selling more water in the dry season was very high at 93\%. That is, most the GSUs did better business in the dry season than in the rainy season. The results also showed that GSU managers with high school or tertiary education had a lower probability of better performance than those with secondary or primary education. As mentioned earlier (Table 10), the number of years that a GSU plant had been in existence was related to the amount of water sold and the number of customers. These results suggest that GSU managers with lower educational levels had got their jobs earlier and had therefore had a longer time to establish a strong customer base. However, there could be other factors affecting the GSU manager's performance that cannot be explained by the model. Next, the time the GSU had been established had an effect on its performance. GSUs built prior to 2001 had a higher probability of better performance compared with those established in the period 2002 to 2006. For instance, GSUs established in the period 2005 to 2006 had a lower probability of good performance at $13.5 \%$ compared with those set up prior to 2004.

\section{Conclusions}

This study has described several ways to deal with the problem of clean water use for three main water sources: rain water, surface water, and groundwater in the VMD. The advantages and constraints of and water treatment techniques for each source were comparatively evaluated to provide a summary of clean water use options for the households of the delta. The final choice of source of water and treatment options was found to depend on the availability and quality of the different sources and the economic situation of the household.

The study showed that non-GSU users extracted groundwater free of charge and also tended to use water from other free sources such as rivers and rain. The use of rain water is now not popular, limited by the problem of storage. In the circumstances, groundwater is the most suitable choice. If all the groundwater required for domestic purposes were to be extracted from the privately owned tube-wells, groundwater would soon be completely depleted. However, GSU users have to pay a price for the water they buy. This is a good thing since pricing the water tends to reduce the volume of water demanded.

A survey of GSU managers found that the probability of consumers switching to GSU water was higher during the dry season as compared to the wet season. The fact that GSU water becomes more popular during the dry season also implies that the use of this resource would help relieve extraction from the shallow aquifer and rivers, thus resulting in improved environmental conditions in the region. Especially in the dry season, water in the VMD's rivers is seriously polluted and presents health hazards for users.

The results showed that three factors affected the quantity of water sold: the distance from GSU plant to the center of the village or commune, education status of the GSU manager, and the time the GSU

Table 11 Results of discriminant analysis of the difference in amount of GSU water sold in the dry and rainy seasons

\begin{tabular}{|c|c|c|c|c|}
\hline Variable & Standardized canonical discriminant coefficient & Structure matrix coefficient & $R_{\mathrm{c}}$ & Wilks' lambda \\
\hline Distance & 0.558 & 0.601 & & \\
\hline Depth & -0.829 & -0.497 & & \\
\hline Manager education & -0.142 & -0.190 & & \\
\hline Capacity & 0.755 & 0.298 & & \\
\hline
\end{tabular}


Table 12 LPM forecasts of GSU performance in the dry and rainy seasons

\begin{tabular}{|c|c|c|c|c|}
\hline & Variable & Coefficient & $t$-value & $R^{2}$ \\
\hline Constant & & 0.51 & $7.321^{* * *}$ & \\
\hline \multicolumn{5}{|c|}{ Manager education } \\
\hline & $\begin{array}{l}\text { High school } \\
\text { and above }\end{array}$ & - & - & \\
\hline & Secondary & 0.135 & $2.654^{* * *}$ & \\
\hline & Primary & 0.133 & 1.186 & \\
\hline \multicolumn{5}{|c|}{ Years GSU established } \\
\hline & Prior to 2001 & - & - & \\
\hline & 2002 to 2004 & -0.033 & -0.354 & \\
\hline & 2005 to 2006 & -0.135 & $-1.968^{* *}$ & \\
\hline \multicolumn{5}{|c|}{ Capacity } \\
\hline & $\begin{array}{c}\text { More than } 150 \\
\text { households }\end{array}$ & - & - & \\
\hline & $\begin{array}{l}\text { Less than } 150 \\
\text { households }\end{array}$ & 0.076 & 0.909 & \\
\hline \multicolumn{5}{|c|}{ Distance } \\
\hline & $\begin{array}{l}\text { More than } \\
3 \mathrm{~km}\end{array}$ & - & - & \\
\hline & Less than $3 \mathrm{~km}$ & 0.033 & 0.384 & \\
\hline & & & & 0.265 \\
\hline
\end{tabular}

Note: ${ }^{* * *},{ }^{* *}$ indicate significance at $1 \%$ and $5 \%$ levels, respectively.

plant was built. Meanwhile, the factors which were found to affect the difference in the water quantities sold in the dry and rainy seasons were the distance from the GSU plant to the centre of the village or commune, the depth of the GSU, and the designed capacity (number of households that the GSU could serve). Among the factors forecasted to contribute to higher quantities of water sold in the dry season compared with the rainy season was the education status of the GSU manager. It was predicted that GSU managers who had lower levels of education (secondary and primary school) would perform better than those with high school or tertiary education. This was a surprising result indicating that some factors like customer relationships were important but were not considered in the study.

The education status of the GSU manager was found to contribute largely to the quantity of water sold monthly in the regression analysis, in that higher educated GSU managers sold more water. However, a LPM analysis of GSU water sales showed that lower educated GSU managers had a higher probability of selling more water in the dry season than their higher educated counterparts. This surprising result indicates that further studies should be done to ascertain other criteria that may be more important than education in contributing to good sales performance by GSU managers.
Among current GSU water users, two-fifths of them used to have their own private tube-wells before switching to GSU water. This result proves that the GSU program is attractive to households. Therefore, the WEMCs should promote the program to every non-GSU household, especially private tube-well owners. The fact that the water consumption is reduced with GSUs indicates that the right way towards sustainable groundwater management is by getting more private tube-well users into the program. The income and size of household were found to be the main factors affecting non-GSU to GSU switching decisions. It is therefore recommended that the WEMCs target large households and those with high incomes.

Besides groundwater and river water, rain water is considered as a potential water source of the rural clean water supply program in the VMD. However, the awareness of the public about pollution of untreated rain water is limited. Each source of water has economic and environmental advantages and disadvantages. Any proposal on water source options should take into account the problem of water pollution, appropriate treatment techniques, and economic factors. It is recommended that an in-depth economic analysis of cost effectiveness should be implemented for the different management alternatives in order to identify the best options for the residents of the delta.

\section{Endnotes}

${ }^{\mathrm{a}} \mathrm{A}$ standardized canonical discriminant coefficient is used to compare the relative importance of the independent variables. Put another way, it indicates the partial contribution of each independent variable to the dependent variable.

${ }^{\mathrm{b}}$ In the survey, a representative GSU was described by the following characteristics (mean values): manager's education level at secondary, the time the GSU was built was in the period 2002 to 2004, the designed capacity was less than 150 households, and the distance to the center of the village was more than $3 \mathrm{~km}$.

\section{Competing interests}

The authors declare that they have no competing interests.

\section{Authors' contributions}

VTD designed the study questionnaire, collected and analyzed the data, and drafted the manuscript. HVK made critical revisions to the manuscript. All

authors read and approved the final manuscript.

Received: 18 June 2014 Accepted: 28 October 2014

Published online: 20 January 2015

\section{References}

Ahmad, J, Goldar, B, \& Misra, S. (2005). Value of arsenic-free drinking water to rural households in Bangladesh. Journal Environment Management, 74(2), 173-185. doi:10.1016/j.jenvman.2004.07.011.

Danh, VT. (2008). Economic Value of Groundwater Protection in the Mekong Delta (CAULES-DANIDA report) Vietnam: Can Tho University, Can Tho City. 
DARD, CT. (2002). Internal Annual Report on Water Resource Management. Can Tho, Vietnam: Can Tho Department of Agriculture and Rural Development (Can Tho DARD).

Hamoudi, A, Jeuland, M, Lombardo, S, Patil, S, Pattanayak, SK, \& Rai, S. (2012). The effect of water quality testing on household behavior: evidence from an experiment in rural India. American Journal of Tropical Medicine and Hygiene, 87(1), 18-22. doi:10.4269/ajtmh.2012.12-0051.

Khai, HV. (2014). The economic benefits of surface water quality improvements: a case of channel in the Mekong Delta, Vietnam. The International Journal of Environmental Sustainability, 9(2), 13.

Kremer, M, Null C, Miguel E \& Zwane A (2008). Trickle Down: Diffusion of Chlorine for drinking water treatment in Kenya (Working paper, Stanford University). http://www.stanford.edu/group/SITE/archive/SITE_2008/segment_1/papers/ de_giorgi_SITE_Trickle_Down.pdf. Accessed 18/6/2014.

Maddala, GS. (1983). Limited-Dependent and Qualitative Variables in Econometrics. Econometric Society Monographs in Quantitative Economics. England: Cambridge University Press.

Nam, PK, \& Son, TVH. (2005). Household Demand for Improved Ware Services in Hoc Chi Minh City: A Comparison of Contingent Valuation and Choice Modeling Estimates. South Bridge Court, Singapore: The Economy and Environment Program for Southeast Asia (EEPSEA).

Phuong, DM, \& Gopalakrishnan, C. (2003). An application of the contingent valuation method to estimate the loss of value of water resources due to pesticide contamination: the case of the Mekong Delta, Vietnam. International Journal of Water Resources D, 19(4), 617-633. doi:10.1080/07900620320000161409.

WEMC. (2005). Internal Report on Manual for Installing and Operating GSU Plant. Can Tho, Vietnam: Can Tho Water and Environment Management Center (WEMC).

\section{Submit your manuscript to a SpringerOpen ${ }^{\circ}$ journal and benefit from:}

- Convenient online submission

- Rigorous peer review

- Immediate publication on acceptance

- Open access: articles freely available online

- High visibility within the field

- Retaining the copyright to your article 